\begin{tabular}{|c|c|}
\hline INESEG & Middle East Journal of Science \\
INTERNATIONAL & https://dergipark.org.tr/mejs \\
ENGINEERING, \\
SCIENCE AND \\
EDUCATION \\
GROUP
\end{tabular}

Research Article

\title{
FATTY ACID CONTENTS OF TWO EDIBLE MUSHROOM SPECIES (CYCLOCYBE AEGERITA AND HYGROPHORUS EBURNEUS) COLLECTED FROM TOKAT REGION
}

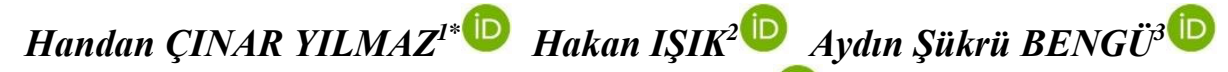 \\ İbrahim TÜRKEKUL ${ }^{4}$ iD \\ 1*Bingöl University, Vocational School of Health Services, Department of Medical Services and Techniques, \\ Program of Medical Laboratory Techniques, Bingöl, Turkey \\ ${ }^{2}$ Tokat M. Emin Saraç Anatolian Religious High School, Tokat, Turkey \\ ${ }^{3}$ Bingöl University, Vocational School of Health Services, Department of Medical Services and Techniques, \\ Program of Medical Laboratory Techniques, Turkey \\ ${ }^{4}$ Gaziosmanpaşa University, Faculty of Arts and Science, Biology Department, Tokat, Turkey \\ * Corresponding author; h.platanus@gmail.com
}

\begin{abstract}
Edible species of mushrooms, which grow naturally and have important ecological tasks, are collected and consumed as a foodstuff in our country as well as in many regions of the world. Many studies to determine the chemical structure of the mushrooms have revealed that they are valuable nutrient sources in terms of essential fatty acids, essential amino acids, vitamins, and minerals. It is especially preferred by people who are dieting because they are poor in terms of calories and fat. This study aimed to determine the fatty acid contents of Cyclocybe aegerita (V. Brig.) Vizzini and Hygrophorus eburneus (Bull.) Fr. Mushroom samples collected from the natural environment. Mushroom samples, which are the material of our study, were collected in Tokat during field trips. The analyzes were performed by GC-MS instrument after obtaining methyl esters of fatty acids. At the end of the studies, palmitic acid C16:0, stearic acid C18:0, oleic acid C18:1(n-9) and linoleic acid C18:2 (n-9-12) from C. aegerita samples; myristic acid C14:0, palmitic acid C16:0, palmitoleic acid C16:1 (n-9), stearic acid C18:0, oleic acid C18:1(n-9), linoleic acid C18:2 (n-9-12), and nervonic acid C24:1(n-9) from H. eburneus samples were determined in different proportions. The highest amount of fatty acid was found linoleic acid in C. aegerita with proportions of $54.33 \%$ and oleic acid in $H$. eburneus samples with proportions of $47.80 \%$. In addition to also in both mushroom species, the total saturated fatty acid rate was higher than the total unsaturated fatty acid rate.
\end{abstract}

Keywords: Cyclocybe aegerita, GC-MS, Hygrophorus eburneus, Tokat, Fatty Acids

Received: May 4, $2020 \quad$ Accepted: June 25, 2020

\section{Introduction}

Mushrooms, as well as playing an important role in the destruction of organic matter in nature are also used as a source of food. Mushrooms have the low-fat content, also are nutritious in terms of high protein, vitamins, fiber, carbohydrates, and minerals they contain. They can be cultivated and used 
extensively in alternative medicine. Dried mushrooms contain $17.5 \%$ protein, $2.9 \%$ fat mostly in the form of the linoleic acid and linolenic acid, $39.9 \%$ carbohydrates, $10 \%$ minerals and provide several vitamins including $\mathrm{C}, \mathrm{D}, \mathrm{K}$, and $\mathrm{B}$ complex vitamins (thiamin, riboflavin, nicotinic acid, biotin) $[1,2,3$, $4,5]$.

Wild edible mushrooms are become more important to human daily life due to their nutritional and chemical composition. Besides these, they have also been reported as therapeutic foods, useful in preventing diseases such as hypertension, hypercholesterolemia, and cancer [6-14]. The lipids are essential biological molecules in cell structure and metabolisms. Besides lipids are more important in energy storage than the caloric energy, protein, or carbohydrates. Lipids play the major functions as critical structural components of biological membranes, provide readily available energy reserves, and serve as essential vitamins and hormones, however, aid in the solubilization of dietary lipids in human health and physiology [7]. In addition, wild edible mushrooms include important fatty acids contents that are mostly not synthesized in the human body. The linoleic fatty acid is reported as omega 6 (W6), linolenic fatty acid as omega 3 (W-3). Omega 6 has important roles in blood circulation and omega 3 is considered the most valuable fatty acid and can be taken from only plants and animal nutrients. Fatty acid compositions have important effects on blood lipid profiles. Saturated fatty acids increase high-density lipoprotein (HDL) cholesterol and reduce low-density lipoprotein (LDL) cholesterol, triacylglycerol, and lipid oxidation [7]. In order to make an analysis of fatty acids with GC-MS, it needs to be derivatized. For this, methylation is often preferred. Gas chromatography is widely used as the most reliable method for the detection of fatty acid esters.

The wild-grown edible mushroom species have seen very variety in Turkey and they have very high potential to consuming and exporting [5]. In many countries, local people usually hunt and eat only known edible mushroom species. Whereas many edible mushroom species aren't known by people and not known medicinal and nutritional features too. So, more edible mushroom species should be introduced to the benefits of the human race. With this study, we want to introduce some wild edible mushroom species that have a very high measure of fatty acids that are very important to the human body.

\section{Materials and Methods}

\subsection{Collection andidentification of mushroomsamples}

The mushroom samples, whose fatty acid contents will be analyzed, were collected from different localities in Tokat province. Some features of the mushroom samples are shown in Table 1.

Table 1. Some features of the analyzed mushroom species

\begin{tabular}{|l|l|l|l|}
\hline Species & Family & Localities & Habitat \\
\hline C. aegerita & Strophariaceae & $\begin{array}{l}\text { Tokat center, Taşliçiftlikköyü } \\
40^{\circ} 19^{\prime} \mathrm{K}, 036^{\circ} 28^{\prime} \mathrm{D}, 640 \mathrm{~m}\end{array}$ & On poplar stump \\
\hline H. eburneus & Hygrophoraceae & $\begin{array}{l}\text { Tokatcenter, Avlunlar village } \\
40^{\circ} 32^{\prime} \mathrm{K}, 036^{\circ} 43^{\prime} \mathrm{D}, 963 \mathrm{~m}\end{array}$ & $\begin{array}{l}\text { On calcareous soil } \\
\text { inmixed woodland }\end{array}$ \\
\hline
\end{tabular}

The color photographs of the samples were taken in their natural environment, then the samples were brought to the laboratory and dried after taking the spore prints. The properties of the microscopic structures (spore and basidium structure and measures, cystidia and pileipellis hyphae structures, clamp 
connection, etc.) of the mushroom samples were obtained from dry samples using some chemical dye sand a Nikon brand research microscope. The samples, whose ecological and morphological features were obtained, were identified with the help of the current literature $[8,9,10,11,12,13]$. The authors of the mushroom names are listed according to the literature [14].

\subsection{Fatty acid analysis}

The fatty acid contents of mushrooms were analyzed at Bingol University Central Research Laboratory.

\subsubsection{Derivatization of fatty acid}

Christie [15] was followed in the preparation of methylesters of fatty acids, after some revisions. With some revision, Hara and Radin [16] were followed for lipid extraction. For this, the plant sample was homogenized in $10 \mathrm{~mL}$ of hexane/isopropanol (3:2) and centrifuged at $5000 \mathrm{rpm}$ for $10 \mathrm{~min}$. The organic phase was removed and placed in the test tubes. Fatty acids need to be derivatized in order to be able to look at GC. Derivatization with methyl esters is often preferred. For this purpose, Christie (1990) method was preferred because it is practical and highly efficient.

According to this method: the lipid extract prepared above was taken out of the mouth-capped tubes to prepare methyl esters. $5 \mathrm{~mL}$ of $2 \%$ methanolic sulfuric acid was added and vortexed. This mixture was left to stand for 15 hours of methylation at $50^{\circ} \mathrm{C}$. At the end of this period, the tubes were removed, cooled to room temperature, and vortexed with the addition of $5 \mathrm{~mL}$ of $5 \% \mathrm{NaCl}$. The fatty acid methyl esters (FAME) formed in the tubes were extracted with $5 \mathrm{~mL}$ of hexane and the hexane phase was taken up from the top and treated with $5 \mathrm{~mL}$ of $2 \% \mathrm{NaHCO} 3$ and waited for 2 hours to separate the phases. The solvent of the mixture containing the methyl esters was then evaporated under nitrogen at $45^{\circ} \mathrm{C}$ and the fatty acids below the test tubes were dissolved in $1 \mathrm{~mL}$ of hexane and analyzed by GC-MS using amber GC vials.

\subsubsection{Analysis of FAME}

A gas chromatograph instrument with an FID and MS (GC-MS, Agilent 7890 GC/5970 MS Series-Santa Clara, CA, USA), and a high polarity capillary column (HP-88, $100 \mathrm{~m} \times 0.25 \mathrm{~mm}, 0.20$ um film (Partno: 112-88A7, Agilent, Santa Clara, CA, USA) was used for fatty acid analyzes. Helium was used as the carrier gas (helium at $1 \mathrm{~mL} \mathrm{~min}^{-1}$ at $120^{\circ} \mathrm{C}$ ). The injector temperature was set at 250 ${ }^{\circ} \mathrm{C}$, and the detector temperature at $250{ }^{\circ} \mathrm{C}$. The oven temperature was initially set at $120^{\circ} \mathrm{C}$ for $2 \mathrm{~min}$ and then raised to $250{ }^{\circ} \mathrm{C}$ at $5{ }^{\circ} \mathrm{C} \mathrm{min}^{-1}$. Because the hold time is 16 minutes, the total analysis is 45 minutes. The detector gas was air set at $350 \mathrm{mLmin}^{-1}$, and hydrogenas was set at $35 \mathrm{mLmin}^{-1}$. The detector makes up gas was nitrogen at $35 \mathrm{mLmin}^{-1}$. Other conditions: split ratio is $1 / 10$, the solvent delay time is 12 minutes, the injection volume is $1 \mathrm{uL}$. An injection system with auto sampler was used (Table 2). GC-FID and MS results were recorded simultaneously. The results were evaluated by pairing with the NIST and WHILEY libraries registered on the device. The FID detector was used to increase the reliability of the analysis. 
Middle East Journal of Science (2020) 6(1): 37-43

Table 2. Condition of gas chromatography

\begin{tabular}{|c|c|}
\hline Condition of Gas Chromatogra & \\
\hline Instrument & Agilent 7890 \\
\hline MS Series & $5970 \mathrm{MS}$ \\
\hline Column & $\mathrm{HP} 88,100 \mathrm{~m} \times 0.25 \mathrm{~mm} \times 0.20 \mu \mathrm{m}$ \\
\hline Carrier gas (Helium) & $1 \mathrm{~mL} \min ^{-1}$ (constant flow) \\
\hline Injector temperature & $250{ }^{\circ} \mathrm{C}$ \\
\hline FID detector temperature & $250{ }^{\circ} \mathrm{C}$ \\
\hline Dried airflow & $350 \mathrm{~mL} \mathrm{~min}-1$ \\
\hline Hydrogen flow & $35 \mathrm{~mL} \mathrm{~min}^{-1}$ \\
\hline Nitrogen (make up) & $35 \mathrm{~mL} \mathrm{~min}^{-1}$ \\
\hline Split ratio & $1 / 10$ \\
\hline Solvent delay time & 12 min. \\
\hline Injection volume & $1 \mu \mathrm{L}$ \\
\hline Oven initial temperature & $120^{\circ} \mathrm{C}$ at $2 \mathrm{~min}$. hold time \\
\hline Final temperature & $250^{\circ} \mathrm{C}$ at $5^{\circ} \mathrm{C} / \mathrm{min}$. and hold time $16 \mathrm{~min}$. \\
\hline Total time & 45 min. \\
\hline Cleaning procedure of injector & Before and after cleaning 3 times with hexane \\
\hline
\end{tabular}

\section{Results and Discussion}

In the present study, the fatty acids composition of the edible mushroom samples collected from Tokat's province was analyzed. The analyzes were performed by the GC-MS instrument after obtaining methyl esters of fatty acids. As a result of the analyzes, different rates of saturated and unsaturated fatty acids were determined. The results for the fatty acid profile, total saturated fatty acids ( $\mathrm{SF}$ As), and polyunsaturated fatty acids ( $\Sigma$ UFAs) of analyzed mushrooms were shown in Table 3.

Table 3. Fatty acid composition of two wild edible mushrooms (\%)

\begin{tabular}{|c|l|c|c|}
\hline Retention Time (min) & Fatty Acid Type & C. aegerita & H. eburneus \\
\hline 19,845 & Myristic acid C14:0 & ND & 0.32 \\
\hline 21,765 & Pentadecanoic acid C15:0 & ND & ND \\
\hline 23,982 & Palmitic acid C16:0 & 22.15 & 21.93 \\
\hline 28,525 & Stearic acid C18:0 & 9.62 & 3.15 \\
\hline & ESFAs & 31.77 & 25.40 \\
\hline
\end{tabular}




\begin{tabular}{|c|l|c|c|}
\hline 24,873 & $\begin{array}{l}\text { Palmitoleic acid C16:1 (n- } \\
9)\end{array}$ & ND & 1.14 \\
\hline 29,320 & Oleic acid C18:1 (n-9) & 13.90 & 47.80 \\
\hline 30,688 & $\begin{array}{l}\text { Linoleic acid C18:2 (n-9- } \\
12)\end{array}$ & 54.33 & 24.88 \\
\hline 41,235 & Nervonic acid C24:1 (n-9) & ND & 0.41 \\
\hline & ¿UFAs & 68.23 & 74.23 \\
\hline
\end{tabular}

ND- not detected

Palmitic, stearic, oleic, and linoleic acid were found in the fruit body of C. aegerita samples with proportions of $22.15 \%, 9.62 \%, 13.90 \%, 54.33 \%$, respectively. In the fruit body of H. eburneus samples; myristic, palmitic, stearic, palmitoleic, oleic, linoleic, and nervonic acid were determined with proportions of $0.32 \%, 21.93 \%, 3.15 \%, 1.14 \%, 47.80 \%, 24.88 \%, 0.41 \%$, respectively. In our analysis, it has been observed that the most amount of fatty acid varies among the mushroom species. While the 41ajör fatty acid was linoleic acid in C. aegerita species with $54.33 \%$, it was oleic acid in H. eburneus species with $47.80 \%$. Also, the most saturated fatty acid type in the studied samples was palmitic acid ranged from $22.15 \%$ (C. aegerita) to $21.93 \%$ (H. eburneus). Myristic, palmitoleic and nervonic acid can only be detected in H. eburneus with proportions of $0.32 \%, 1.14 \%, 0.41 \%$, respectively. In both the species $\Sigma$ UFAs were higher than $\Sigma$ SFAs (Tablo 3). Especially unsaturated fatty acids are very important in human nutrition. Because some of these (such as linoleic acid) are not produced in the human body, they must be taken from the outside.

In a study to determine the chemical content on Agrocybeaegerita (Syn: C. aegerita) [17], about 24 fatty acid kind were found at different rates. In this study it was found that the most abundant fatty acid was linoleic acid (78.40\%). The other rates are palmitic acid (13.07\%), oleic acid (3.03\%), and stearic acid (2.13\%). The amounts of other fatty acids were found to be very low $(<1 \%)$. In our study, linoleic, palmitic, oleic and stearic acid rates were similar to the results of this study. However, the amount of oleic acid determined in our analysis was higher than this study. Also, similar to our work, in this study, it was observed that $\Sigma$ UFAs (82.07\%) was higher than $\Sigma$ SFAs (17.93\%).

The other studies have been made to detect fatty acids on Agrocybe cylindracea (Syn: Cyclocybe cylindracea), a similar species with C. aegerita [18]. Similarly with our result, linoleic acid was the major fatty acid $(66.72 \%)$ detected in their study, and other fatty acids were palmitic (15.23\%), stearic (5.52\%), oleic acid (1.84\%). They also determined that $\Sigma$ UFAs $(71.96 \%)$ was higher than $\Sigma$ SFAs $(28.13 \%)$.

Edible mushrooms have become the preferred foods in recent years because they are low in fat but especially rich in unsaturated fatty acids. Therefore, many studies have been carried out in our country, as in the whole world, to determine the fatty acid content of these foods. Another study has been made on wild edible mushroom "Bovista plumbea" to determine its fatty acid profile [19]. As a result of this, they determined that the most abundant detected fatty acids were C21:0, C20:1, C22:0, $\mathrm{C} 18$, and isomers of $\mathrm{C} 18$. Tricholomopsis rutilans has been analyzed to determine the fatty acid contents [20]. Oleic, linoleic, palmitic and stearic acid were the highest rates of fatty acid detected with proportions of 39.04, 37.09, 17.14, 4.18\%, respectively. Also, three wild mushrooms Coprinopsis atramentaria, Laetiporus sulphureus, and Suillus luteus were studied to detect the fatty acid profiles. 
The main fatty acid was oleic acid with $33.94 \%$ in L. sulphureus, andlinoleic acid in C. atramentaria and S. Luteus [21].

The results of our study and earlier studies show that mushrooms that are collected from the natural environment and grown in the culture medium are particularly rich in unsaturated fatty acids.

\section{Conclusion}

In addition to being economical, edible mushrooms that grow naturally in woodland or meadow areas have become the preferred foodstuffs today due to the chemicals they contain and their medical and pharmacological effects such as anticancer, antioxidant or antimicrobial effects. Our country is very rich in terms of mushroom diversity besides plant diversity. Many studies are carried out to determine mushroom biodiversity. These studies have shown that very few of the edible mushrooms grown in a region are known and consumed by humans. C. Aegerita and H. eburneus macrofungi grown naturally are also not very known as edible mushrooms. The results of our study showed that these two mushroom species are rich in unsaturated fatty acids.

The compliance to Research and Publication Ethics: This work was carried out by obeying research and ethics rules.

\section{Acknowledgment}

We would like to thank Bingöl University Central Research Laboratory staff and managers for the chemical analysis of mushrooms. This study was presented as an oral presentation at the $1^{\text {st }}$ International Malatya Applied Sciences Congress (20-22 December 2019, Malatya).

\section{References}

[1] Anderson, S.C., Cockayne, S., "Clinical Chemistry Concepts and Application", McGraw-Hill, Medical Publishing Division, 2003.

[2] Ayaz, F.A., Torun, H., Özel, A., Çöl, M., Duran, C., Sesli, E., Çolak, A., "Nutritional value of some wild edible mushrooms from Black Sea Region (Turkey)", Turkish Journal of Biochemistry, 36(3), 213-221, 2011.

[3] Pekşen, A., Kibar, B., Yakupoğlu, G., "Yenilebilir bazı Lactarius türlerinin morfolojik özelliklerinin, protein ve mineral içeriklerinin belirlenmesi”, OMÜ Zir. Fak. Dergisi, 22(3), 301-305, 2007.

[4] Pekşen, A., Yakupoğlu, G., Kibar, B., "Some chemical components of Lactarius pyrogalus from diverse locations", Asian Journal of Chemistry, 20(4), 3109-3114, 2008.

[5] Demirbaş, A., "Concentrations of 21 Metals in 18 Species of Mushrooms Growing in the East Black Sea Region", Food Chemistry, 75, 453-457, 2001.

[6] Manzi, P., Aguzzi, A., and Pizzoferrato, L., "Nutritional value of mushroom widely consumed in Italy", Food Chemistry, 73, 321-325, 2001.

[7] Barros, L., Baptista, P., Correia, D.M., Casal, S., Oliveira, B., Ferreira, I.C.F.R., "Fatty acid and sugar compositions, and nutritional value of five wild edible mushrooms from Northeast Portugal”, Food Chemistry, 105, 140-145, 2007. 
[8] Bon, M., The Mushrooms and Toad stools of Britain and North-Western Europe, Hodder-Stoughton, London, 1987.

[9] Breitenbach J., Kränzlin F., Fungi of Switzerland. Vol: 3, Boletes and Agarics 1. Part, VerlagMykologia CH-6000 Luzern 9, Switzerland, 1991.

[10] Breitenbach, J., Kränzlin, F., Fungi of Switzerland. Vol: 4, Agarics 2. Part, Verlag Mykologia CH6000 Luzern 9, Switzerland, 1995.

[11] Jordan, M., The Encyclopedia of Fungi of Britain and Europe, Frances Lincoln, London, 1995.

[12] Moser, M., Keys to Agarics and Boleti, Gustav Fischer Verlag, Stuttgart, 1983.

[13] Phillips, R., Mushrooms and Other Fungi of Great Britain \& Europe, Pan Books Ltd., London, 1981.

[14] Kirk, P., Index Fungorum, URL:http://www.indexfungorum.org (accessed 25 March 2020), 2011.

[15] Christie, W.W., Gas Chromatography and Lipids: A Practical Guide, The Oily Press Ltd. Scotland, 1990.

[16] Hara, A., Radin, N.S., "Lipid extraction of tissues with a low-toxicity solvent", Analytical Biochemistry, 90, 420-426, 1978.

[17] Petrović, J., Glamočlija, J., Stojković, D., Ćirić, A., Barros, L., Ferreira, I.C.F.R., Soković, M., "Nutritional value, chemical composition, antioxidant activity and enrichment of cream cheese with chestnut mushroom Agrocybe aegerita (Brig.) Sing", The Journal of Food Science and Technology, 52(10), 6711-6718, 2015.

[18] Ergönül, P.G., Ergönül, B., Kalyoncu, F., Akata, I., "Fatty acid compositions of five wild edible mushroom species collected from Turkey", International Journal of Pharmacology, 8(5), 463 466, 2012.

[19] Durmaz, F., Aktaş, S., Şimşek Sezer, E.N., “Bovista plumbea Pers.'nın yağ asiti içeriklerinin incelenmesi”, Mantar Dergisi ,8(2), 104-108, 2017.

[20] Işık, H., Türkekul, İ., Çınar Yılmaz, H., Bengü, A.Ş., "Determination of fatty acid profile and mineral contents of Tricholomopsis rutilans collected from Yozgat" Anatolian Journal of Botany, 3(2), 64-68, 2019.

[21] Bengü, A.Ş., "Some elements and fatty acid profiles of three different edible mushrooms from Tokat province in Turkey", Progress in Nutrition, 21-1, 189-213, 2019. 